\title{
Effect of Nitrogen Source on Lipid Accumulation in Oleaginous Yeasts
}

\author{
By CHRISTOPHER T. EVANS $\dagger$ AND COLIN RATLEDGE* \\ Department of Biochemistry, University of Hull, Hull HU6 7RX, UK
}

(Received 14 November 1983)

\begin{abstract}
The effect of various nitrogen sources on lipid accumulation by 17 species and strains of yeast was examined. Organic nitrogen sources resulted in considerably increased lipid contents only in strains of Rhodosporidium toruloides. Lipid accumulation in Rs. toruloides CBS 14 increased from $18 \%(\mathrm{w} / \mathrm{w})$, with $\mathrm{NH}_{4} \mathrm{Cl}$ as nitrogen source, to above $50 \%(\mathrm{w} / \mathrm{w})$ when glutamate, urea or arginine was used. Stimulation of lipid production by glutamate was not observed when the yeast was grown in continuous culture with nitrogen-limiting medium. The increase in lipid content of glutamate-grown cells in batch culture was accompanied by a marked increase in the intracellular citrate concentration and its excretion from the cells. The pattern of citrate accumulation in glutamate-grown cells was mirrored by the accumulation of other metabolites, especially 2-oxoglutarate and $\mathrm{NH}_{4}^{+}$ions, which were produced as a result of the increased catabolism of glutamate. It is proposed that the products of glutamate metabolism in $R s$. toruloides play a major role in regulating the flux of carbon to precursors of lipid biosynthesis, such as citrate.
\end{abstract}

\section{INTRODUCTION}

Work in our laboratory has been concerned with the biochemistry of various oleaginous yeasts which can accumulate large quantities of lipid (Ratledge, 1978, 1982; Rattray et al., 1975). When the nitrogen source in the medium becomes depleted, protein and nucleic acid synthesis ceases but excess carbon continues to be metabolized to lipid. Under such conditions, nonoleaginous yeasts do not accumulate lipid. A hypothesis explaining lipid accumulation in yeasts has been proposed by Botham \& Ratledge (1979). This states that intramitochondrial citrate accumulates primarily due to the decrease in intracellular AMP concentration, which leads to a decline in activity of the AMP-dependent $\mathrm{NAD}^{+}:$isocitrate dehydrogenase in the mitochondria. Citrate is then transported across the mitochondrial membrane in exchange for L-malate (Evans et al., 1983) and is cleaved in the cytosol by ATP : citrate lyase to yield acetyl-CoA (and oxaloacetate), from which fatty acids are synthesized.

Certain yeasts, however, have been reported to produce higher concentrations of lipid when grown with an organic, rather than an inorganic, nitrogen source (Woodbine, 1959; Blinc \& Hočevar, 1953; Witter et al., 1974). No explanation for this has been forthcoming. In this paper, we have examined the effects of nitrogen sources on the lipid content of various yeasts. From such a study we hope to gain insight into the biochemical processes and control mechanisms operating in oleaginous yeasts and then be able to manipulate these to advantage.

\section{METHODS}

Yeasts. The yeasts used for this work were obtained from: the Central Bureau voor Schimmelcultures (CBS), Baarn, Holland; the National Collection of Yeast Cultures (NCYC), Food Research Institute, Norwich, UK; and the Institute for Fermentation (IFO), Osaka, Japan. Candida curvata D and Trichosporon cutaneum 40 were the kind gift of Professor E. G. Hammond, Iowa State University, USA.

† Present address: Department of Cellular and Molecular Biology, University of Michigan, Ann Arbor, Michigan 48109, USA.

Abbreviation: GDH glutamate dehydrogenase. 
Media. The glucose/salts medium for both batch and continuous culture experiments was that described by Evans et al. (1983). Glucose was used as sole carbon source in all experiments at $30 \mathrm{~g} 1^{-1}$. All nitrogen sources were added to give $0.13 \mathrm{~g} \mathrm{~N}^{-1}$. The $\mathrm{pH}$ was adjusted to 5.5 prior to sterilization. All amino acids were sterilized by filtration and then added to media prior to inoculation.

Culture conditions. Yeasts were grown at $30^{\circ} \mathrm{C}$ as batch cultures either in shake-flask $(100 \mathrm{ml}$ medium in $250 \mathrm{ml}$ flask) or 1-litre vortex-aerated vessels without $\mathrm{pH}$ control. Continuous cultivation was carried out in a 1-litre chemostat (LH 500 series 11, LH Engineering, Stoke Poges, Bucks., UK) with the pH maintained at 5.5 by the automatic addition of $\mathrm{NaOH}$. Addition of antifoam was maintained at preset intervals using an appropriate metering pump and timing clock. Incoming air was passed through two fibre-glass filters connected in series; the aeration rate was maintained at $1 \mathrm{vol}$. air per vol. medium per min. The volume within the fermenter was kept constant by using an overflow weir ( $5 \mathrm{~mm}$ diameter). Agitation, with flat-bladed impellers, was at 500 r.p.m. Steady-state conditions were maintained for at least six complete changes of medium in the vessel before alteration.

Biomass and other determinations. Samples $(10 \mathrm{ml})$ were centrifuged at $5000 \mathrm{~g}$ for $5 \mathrm{~min}$ in preweighed, dried tubes and washed twice with $10 \mathrm{ml}$ distilled water. The pellets were dried at $80^{\circ} \mathrm{C}$ over $\mathrm{P}_{2} \mathrm{O}_{5}$ in a vacuum oven to constant weight. Lipid was determined by a method based on that of Folch et al. (1957); ammonia was determined by the method of Chaney \& Marbach (1962); citrate by the method of Dagley (1974); L-malate by the method of Gutmann \& Wahlefeld (1974); DL-isocitrate by the method of Siebert (1974); 2-oxoglutarate by the method of Bergmeyer \& Bernt (1974); L-glutamate by the method of Bernt \& Bergmeyer (1974); glucose 6-phosphate (and fructose 6-phosphate) by the method of Lang \& Michal (1974) and oxaloacetate by the method of Wahlefeld (1974).

Preparation of intracellular extracts ( for isolation of metabolites). $\mathrm{A} \mathrm{HClO}_{4}$ digestion of washed cells was carried out according to the procedure described by Evans \& Ratledge (1983b).

Preparation of cell extracts. Extracts were prepared by passage through a French pressure cell following the procedure described by Evans \& Ratledge (1983b).

Enzyme assays. Protocols for the assay of ATP : citrate lyase (EC 4.1.3.8), $\mathrm{NAD}^{+}$and $\mathrm{NADP}^{+}$-dependent isocitrate dehydrogenase (EC 1.1.1.41), glucose-6-phosphate dehydrogenase (EC 1.1.1.49), $\mathrm{NAD}^{+}$-malate dehydrogenase (EC 1.1.1.37), malic enzyme (EC 1.1.1.40), citrate synthase (EC 4.1.3.7), pyruvate carboxylase (EC 6.4.1.1), pyruvate dehydrogenase (EC 1.2.4.1), aconitase (EC 4.2.1.3) were as described by Evans \& Ratledge (1983b). Phosphofructokinase (EC 2.7.1.11) was assayed by the method of Sols \& Salas (1966); pyruvate kinase (EC 2.7.1.40) by the method of Bücher \& Pfleiderer (1955), fructose-1,6-bisphosphate aldolase (EC 4.1.2.13) by the method of Rutter $e$ al. (1966), and $\mathrm{NAD}^{+}$- and NADP ${ }^{+}$-dependent glutamate dehydrogenases (EC 1.4.1.2 and 1.4.1.4) by the method of Doherty (1970). Protein was determined by the method of Bradford (1976). $\mathrm{NAD}^{+}$: glutamate dehydrogenase and $\mathrm{NADP}^{+}$: glutamate dehydrogenase were partially purified from extracts of glutamate- and $\mathrm{NH}_{4}^{+}$-grown cells, respectively. Cell extracts were fractionated with $\left(\mathrm{NH}_{4}\right)_{2} \mathrm{SO}_{4}$ with the 40 to $70 \%$ saturation fraction being retained. The fractions were desalted by passage through a $30 \times 2.5 \mathrm{~cm}$ column of Sephadex G-50.

Studies with $\left[\mathrm{U}^{-14} \mathrm{Clglutamate}\right.$ and $\left[1,2 \cdot{ }^{14} \mathrm{C}\right]$ acetate. [U- $\left.{ }^{-14} \mathrm{C}\right] \mathrm{Glutamate}\left[5 \mu \mathrm{Ci} ; 52.6 \mu \mathrm{Ci} \mu \mathrm{mol}^{-1}(1.95\right.$ $\left.\left.\mathrm{MBq} \mu \mathrm{mol}^{-1}\right)\right]$ or $\left[1,2^{-14} \mathrm{C}\right]$ acetate $\left[5 \mu \mathrm{Ci} ; 60 \mu \mathrm{Ci}_{\mu \mathrm{mol}^{-1}}\left(2.22 \mathrm{MBq} \mu \mathrm{mol}^{-1}\right)\right]$ was added to cultures of Rhodosporidium toruloides $\mathrm{CBS} 14$ growing in 1-litre vortex-aerated vessels at $30^{\circ} \mathrm{C}$. Samples $(1 \mathrm{ml})$ were filtered through Whatman grade A glass-fibre paper discs which had been pre-washed with distilled water. The cells were washed once with $0.9 \%(\mathrm{w} / \mathrm{v}) \mathrm{NaCl}$ and once with a buffer containing $40 \mathrm{~mm}-\mathrm{Tris} / \mathrm{HCl} \mathrm{pH} \mathrm{7.0,0.6} \mathrm{M-sorbitol} \mathrm{and} 0.9 \mathrm{mM}-$ EDTA. The whole filter paper disc was transferred to a glass scintillation vial, dissolved in $1 \mathrm{ml}$ Soluene (Packard Instruments) and taken up in $10 \mathrm{ml}$ of a toluene-based scintillation fluid. Lipid was extracted, as previously described, redissolved in chloroform and counted in a toluene-based scintillant. Residual radiolabel was estimated in culture filtrates using a dioxane-based scintillant containing: $4 \mathrm{~g}$ diphenyloxazole, $60 \mathrm{~g}$ naphthalene, $20 \mathrm{ml}$ ethanediol, $100 \mathrm{ml}$ methanol and $880 \mathrm{ml}$ dioxane.

\section{RESULTS}

\section{Effect of nitrogen sources on lipid accumulation in yeasts}

The influence of three different nitrogen sources, namely $\mathrm{NH}_{4} \mathrm{Cl}$, asparagine and glutamate, on lipid and biomass production by 17 yeasts is shown in Table 1 . Only a small number of the yeasts showed any variation in lipid content; the most significant of these were all strains of Rhodosporidium toruloides. Strain CBS 6016 was no exception to this finding, although previously it had been regarded as non-oleaginous because of a failure to detect ATP : citrate lyase in cell extracts (Boulton \& Ratledge, 1981). However, this yeast has been re-examined in the light of the above findings and activity of ATP : citrate lyase has been detected (S. Gilbert, 
Table 1. Effect of different nitrogen sources on the production of biomass and lipid by various yeasts

All yeasts were grown in batch culture in 1-litre vortex-aerated vessels at $30^{\circ} \mathrm{C}$. Nitrogen sources were added to give $0 \cdot 13 \mathrm{~g} \mathrm{~N}^{-1}$. Cultures were harvested after $120 \mathrm{~h}$ growth.

\begin{tabular}{|c|c|c|c|c|c|c|}
\hline \multicolumn{3}{|c|}{$\begin{array}{l}\text { Nitrogen } \\
\text { source . }\end{array}$} & \multicolumn{2}{|c|}{ Asparagine } & \multicolumn{2}{|c|}{ L-Glutamate } \\
\hline & $\begin{array}{c}\text { Biomass } \\
\left(\mathrm{g} \mathrm{l}^{-1}\right)\end{array}$ & $\begin{array}{c}\text { Lipid } \\
(\%, w / w)\end{array}$ & $\begin{array}{c}\text { Biomass } \\
\left(\mathrm{g} \mathrm{l}^{-1}\right)\end{array}$ & $\begin{array}{c}\text { Lipid } \\
(\%, w / w)\end{array}$ & $\begin{array}{c}\text { Biomass } \\
\left(\mathrm{g}^{-1}\right)\end{array}$ & $\begin{array}{c}\text { Lipid } \\
(\%, w / w)\end{array}$ \\
\hline & $11 \cdot 2$ & 33 & $11 \cdot 7$ & 37 & $11 \cdot 4$ & 35 \\
\hline & $8 \cdot 9$ & 6 & $8 \cdot 0$ & 8 & $9 \cdot 2$ & 8 \\
\hline & $10 \cdot 4$ & 22 & $10 \cdot 4$ & 29 & $10 \cdot 4$ & 30 \\
\hline & $10 \cdot 5$ & 38 & $10 \cdot 6$ & 35 & $9 \cdot 8$ & 38 \\
\hline & $9 \cdot 5$ & 26 & $9 \cdot 4$ & 26 & $10 \cdot 4$ & 33 \\
\hline & $9 \cdot 4$ & 28 & 9.9 & 30 & $9 \cdot 0$ & 32 \\
\hline & 9.9 & 39 & 9.8 & 34 & $9 \cdot 4$ & 34 \\
\hline & $10 \cdot 2$ & 43 & $9 \cdot 2$ & 45 & 9.9 & 40 \\
\hline & 9.9 & 18 & $10 \cdot 8$ & 39 & $10 \cdot 9$ & 51 \\
\hline 59 & $10 \cdot 2$ & 33 & $10 \cdot 9$ & 42 & $10 \cdot 6$ & 49 \\
\hline 190 & $11 \cdot 0$ & 25 & $10 \cdot 4$ & 27 & $10 \cdot 9$ & 32 \\
\hline 16 & $10 \cdot 9$ & 15 & $11 \cdot 2$ & 34 & $11 \cdot 0$ & 44 \\
\hline & 6.9 & 23 & $7 \cdot 2$ & 23 & $6 \cdot 6$ & 23 \\
\hline & 8.9 & 19 & $7 \cdot 4$ & 23 & $7 \cdot 6$ & 20 \\
\hline & $8 \cdot 0$ & 24 & $9 \cdot 6$ & 29 & $8 \cdot 0$ & 27 \\
\hline Jנ & $7 \cdot 4$ & 4 & $7 \cdot 8$ & 5 & $7 \cdot 4$ & 4 \\
\hline & $10 \cdot 2$ & 24 & $10 \cdot 2$ & 32 & $10 \cdot 9$ & 38 \\
\hline
\end{tabular}

Candida curvata D

Candida utilis NCYC 359

Hansenula saturnus CBS 5761

Lipomyces lipofer CBS 944

Lipomyces lipofer CBS 5482

Lipomyces starkeyi CBS 1807

Lipomyces starkeyi CBS 1809

Lipomyces starkeyi CBS 6047

Rhodosporidium toruloides CBS 14

Rhodosporidium toruloides IFO 0559

Rhodosporidium toruloides CBS 5490

Rhodosporidium toruloides CBS 6016

Rhodotorula glutinis NCYC 59

Rhodotorula graminis CBS 5811

Rhodotorula graminis NCYC 502

Saccharomyces cerevisiae NCYC 33*

Trichosporon cutaneum 40

* Non-oleaginous; ATP : citrate lyase negative (cf. Boulton \& Ratledge, 1981).

unpublished). The difference in results may be attributable to an unstable genetic make-up of this strain, which is a cross between two other strains of Rs. toruloides.

Growth on the different nitrogen sources had little effect on total biomass production and did not significantly decrease lipid production in any of the yeasts tested. In the cases where the lipid contents did vary, glutamate gave the highest increases. The largest increase in lipid content was found with Rs. toruloides CBS 14, in which it increased almost threefold, from $18 \%$ to $51 \%$ of the biomass. Figure 1 shows the striking change in cell morphology when the yeast was grown under the different conditions. This yeast was consequently chosen as a model organism for the investigation of this phenomenon.

The effect of a range of nitrogen sources on lipid accumulation by Rs. toruloides CBS 14 is shown in Table 2. All 20 nitrogenous compounds were able to support growth; the range in variation in final biomass concentration was only $1.7 \mathrm{~g}^{-1}$. The final lipid contents varied considerably, however. Inorganic nitrogenous compounds, including ammonium tartrate, produced less than $25 \%$ (w/w) lipid, whilst 12 of the organic sources increased lipid production to over $40 \%$ of the biomass.

\section{Lipid accumulation by Rs. toruloides CBS 14 in batch culture}

Figure 2 shows the patterns of lipid accumulation of $R$ s. toruloides CBS 14 grown with $\mathrm{NH}_{4} \mathrm{Cl}$ or L-glutamate as nitrogen source. The time course of nitrogen exhaustion from the medium and biomass and lipid production were similar to those observed previously with Rhodotorula spp. (Enebo et al., 1946; Kessell, 1968) and other oleaginous yeasts (Evans \& Ratledge, 1983a). Up until $30 \mathrm{~h}$ growth, both culture profiles were similar but then changed abruptly as the glutamate culture began to accumulate substantially more lipid, which eventually reached $52 \%$ of the biomass.

The specific activities of 15 enzymes in cells from both $\mathrm{NH}_{4}^{+}$- and glutamate-grown cultures were determined to see if there were any obvious differences in the pathways of glucose catabolism and citrate metabolism which could relate to the different lipid contents of the cells 


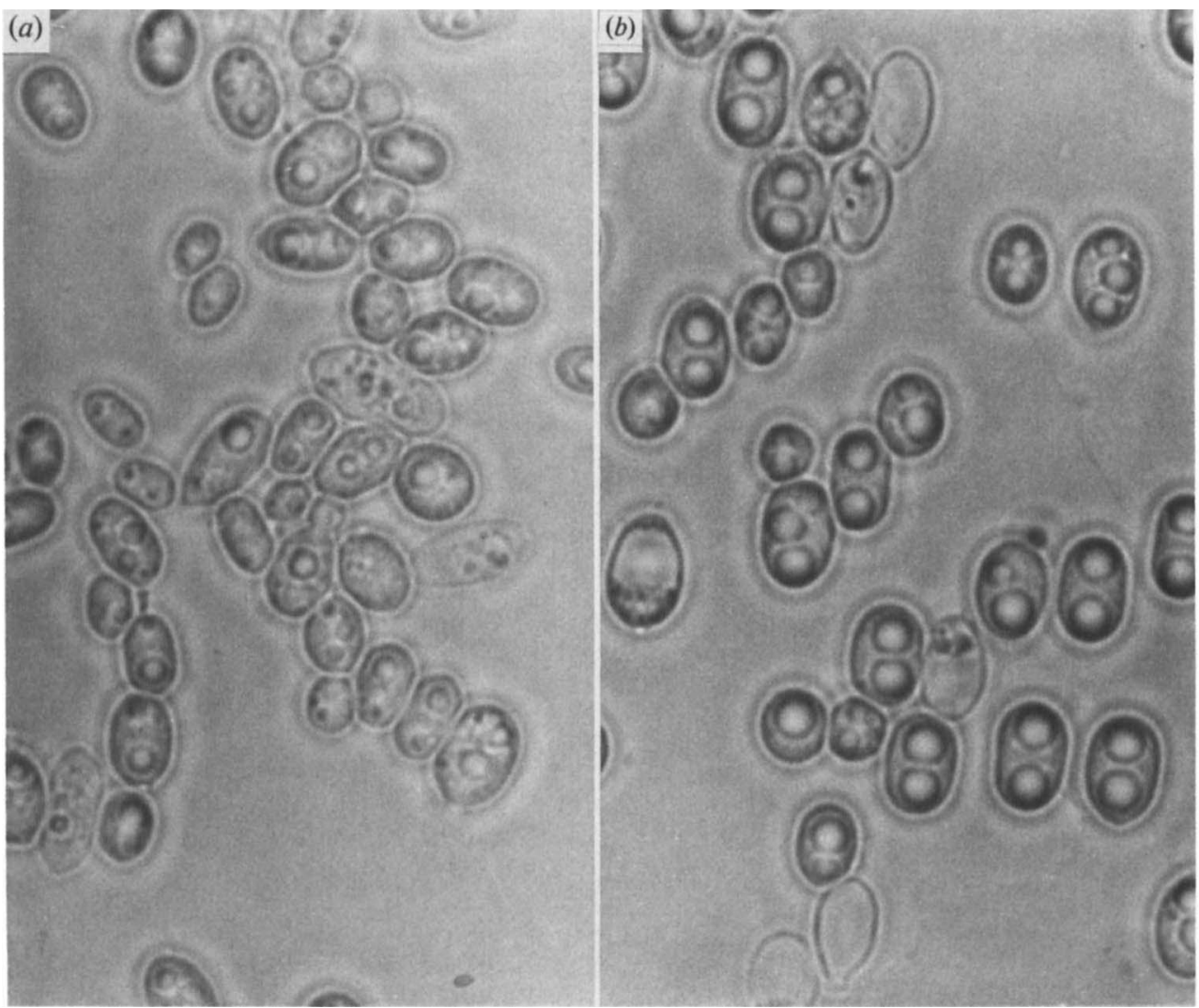

Fig. 1. Rhodosporidium toruloides CBS 14 grown on glucose with (a) $\mathrm{NH}_{4}^{+}$, lipid content $18 \% ;(b)$ glutamate, lipid content $52 \%$. Both photomicrographs taken without staining, negative phase, magnification $=\times 1250$. The low-lipid cells contain two small oil droplets, one at each end of the cell. The high-lipid cells show the two much larger oil droplets.

Table 2. Effect of various nitrogen sources on lipid accumulation by Rs. toruloides CBS 14

Cultures were grown in $250 \mathrm{ml}$ shake flasks for $6 \mathrm{~d}$ at $30^{\circ} \mathrm{C}$ with each nitrogen source at $0.13 \mathrm{~g} \mathrm{~N} \mathrm{l}^{-1}$.

\begin{tabular}{lccccc}
\multicolumn{1}{c}{ Nitrogen source } & $\begin{array}{c}\text { Biomass } \\
\left(\mathrm{g} \mathrm{I}^{-1}\right)\end{array}$ & $\begin{array}{c}\text { Lipid } \\
(\%, \mathrm{w} / \mathrm{w})\end{array}$ & Nitrogen source & $\begin{array}{c}\text { Biomass } \\
\left(\mathrm{g} \mathrm{I}^{-1}\right)\end{array}$ & $\begin{array}{c}\text { Lipid } \\
(\%, \mathrm{w} / \mathrm{w})\end{array}$ \\
$\mathrm{NH}_{4} \mathrm{Cl}$ & $9 \cdot 9$ & 18 & Citrulline & $9 \cdot 2$ & 44 \\
$\left(\mathrm{NH}_{4}\right)_{2} \mathrm{SO}_{4}$ & $9 \cdot 4$ & 18 & Threonine & $10 \cdot 4$ & 46 \\
$\mathrm{Ammonium}$ & $9 \cdot 8$ & 20 & Aspartate & $9 \cdot 5$ & 46 \\
$\mathrm{NaNO}_{3}$ & $9 \cdot 0$ & 21 & Asparagine & $9 \cdot 9$ & 46 \\
Leucine & $8 \cdot 7$ & 29 & Ornithine & $9 \cdot 2$ & 48 \\
Serine & $9 \cdot 2$ & 30 & Proline & $9 \cdot 8$ & 49 \\
Lysine & $8 \cdot 9$ & 32 & Allantoin & $9 \cdot 0$ & 51 \\
Glycine & $9 \cdot 6$ & 38 & Urea & $10 \cdot 3$ & 52 \\
Alanine & $9 \cdot 9$ & 42 & Glutamate & $10 \cdot 0$ & 52 \\
Glutamine & $10 \cdot 1$ & 43 & Arginine & $9 \cdot 8$ & 54
\end{tabular}

(Table 3). However, no significant variation in the activity of any enzyme was found. The intracellular concentrations of numerous intermediary metabolites throughout the progress of the batch cultures are given in Fig. 3(a-h). The excretion of citrate into the medium was fivefold higher in the glutamate-grown culture than in the $\mathrm{NH}_{4}^{+}$-grown culture. Citrate excretion, as observed previously with C. curvata (Evans \& Ratledge, 1983b) and with Lipomyces starkeyi (Boulton \& Ratledge, 1983), did not begin until nitrogen had become exhausted from the 


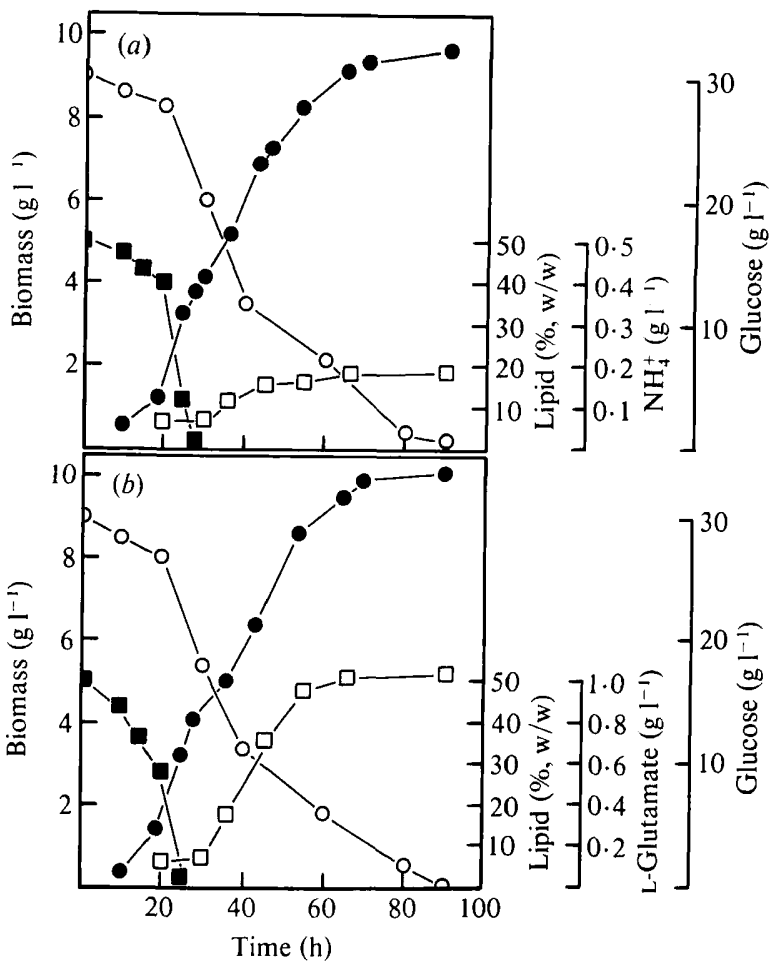

Fig. 2. Growth and lipid accumulation by Rs. toruloides CBS 14 in batch culture. The medium contained $30 \mathrm{~g}$ glucose $\mathrm{l}^{-1}$ as carbon source and the nitrogen sources were : $(a) \mathrm{NH}_{4} \mathrm{Cl}\left(0.5 \mathrm{~g} \mathrm{l}^{-1}\right)$ and (b) L-glutamate $\left(1.03 \mathrm{~g}^{-1}\right)$. $\bigcirc$, Glucose; $\boldsymbol{O}$, biomass; $\square$, lipid; $\square$, nitrogen source.

Table 3. Activities of cytoplasmic and mitochondrial enzymes in Rs. toruloides CBS 14

Cells were harvested after $40 \mathrm{~h}$ growth and separated into mitochondrial and cytosolic fractions as described by Evans et al. (1983). Specific activities are expressed in nmol substrate converted (mg protein) $)^{-1} \min ^{-1}$.

\section{Enzyme}

ATP : citrate lyase

$\mathrm{NAD}^{+}:$isocitrate dehydrogenase

$\mathrm{NADP}^{+}$: isocitrate dehydrogenase

$\mathrm{NAD}^{+}$: glutamate dehydrogenase

$\mathrm{NADP}^{+}$: glutamate dehydrogenase

Glucose-6-phosphate dehydrogenase

$\mathrm{NAD}^{+}$: malate dehydrogenase

Malic enzyme

Citrate synthase

Pyruvate carboxylase

Pyruvate dehydrogenase

Aconitase

Phosphofructokinase

Pyruvate kinase

Aldolase

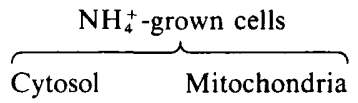

$\begin{array}{rr}74 & 0 \\ 0 & 124 \\ 98 & 0 \\ 42 & 12 \\ 423 & 78 \\ 699 & 11 \\ 1878 & 2673 \\ 79 & 0 \\ 41 & 5010 \\ 4 & 89 \\ 0 & 112 \\ 0 & 83 \\ 142 & 0 \\ 897 & 6 \\ 949 & 4\end{array}$

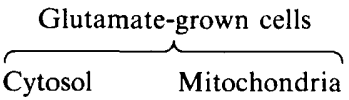

$\begin{array}{rr}82 & 0 \\ 3 & 109 \\ 102 & 0 \\ 64 & 24 \\ 546 & 59 \\ 771 & 0 \\ 2006 & 3015 \\ 106 & 0 \\ 49 & 4973 \\ 0 & 12 \\ 0 & 119 \\ 0 & 79 \\ 199 & 0 \\ 1066 & 10 \\ 994 & 8\end{array}$

medium ( $25-30 \mathrm{~h})$ and, by $40 \mathrm{~h}$ growth, eight times as much citrate had been excreted by the glutamate-grown cells as compared with the $\mathrm{NH}_{4}^{+}$-grown cells (see Fig. $3 a$ ). The intracellular concentrations of citrate also varied considerably between the two cultures (Fig. $3 b$ ). The concentration of citrate increased steadily over the first $40 \mathrm{~h}$ growth in the glutamate-grown cells, reaching a peak value which was 14 times that in the $\mathrm{NH}_{4}^{+}$-grown cells. After $40 \mathrm{~h}$, the 

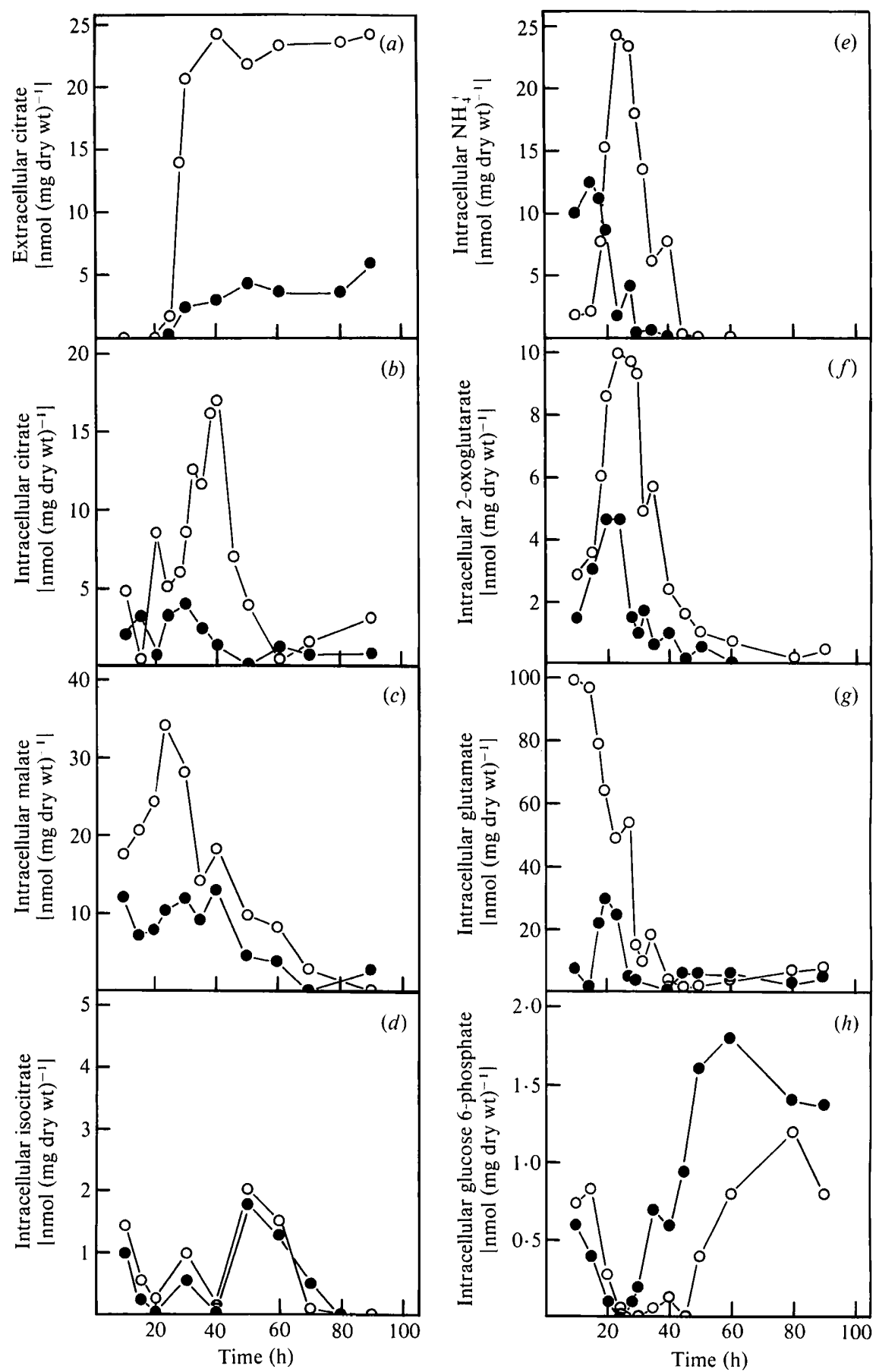

Fig. 3. Concentrations of metabolites in cells of Rs. toruloides CBS 14 during batch culture. Closed circles, $\mathrm{NH}_{4}^{+}$-grown cells; open circles, glutamate-grown cells. (a) Extracellular citrate. Intracellular concentrations of metabolites: $(b)$ citrate, $(c)$ malate, $(d)$ isocitrate. $(e) \mathrm{NH}_{4}^{+},(f)$ 2-oxoglutarate, $(g) \mathrm{L}$ glutamate, $(h)$ glucose 6-phosphate.

concentration of citrate in the intracellular pool decreased steadily until both cultures contained a basal concentration of citrate.

The intracellular concentration of malate was threefold higher in the glutamate-grown cells 
than in the $\mathrm{NH}_{4}^{+}$-grown cells during the first $30 \mathrm{~h}$ growth but then decreased throughout the rest of growth, as it did in the $\mathrm{NH}_{4}^{+}$-grown cells (Fig. 3c). Interestingly, the concentration of malate throughout growth was always higher than the concentration of citrate, in both cultures. The intracellular concentration of isocitrate was low and almost the same in both cultures, with a peak occurring after $50 \mathrm{~h}$ growth (Fig. $3 d$ ). Oxaloacetate and fructose 6-phosphate (not shown in Fig. 3) were present only in trace amounts $(<0.2 \mathrm{nmol}$ per mg cell dry wt) in the cell extracts.

The most significant difference between the two cultures was in the contents of intracellular $\mathrm{NH}_{4}^{+}$(Fig. 3e). Cells from the $\mathrm{NH}_{4} \mathrm{Cl}$ culture contained six times as much $\mathrm{NH}_{4}^{+}$during the first $15 \mathrm{~h}$ growth as did glutamate-grown cells, but this concentration then rapidly decreased to a basal level by $30 \mathrm{~h}$ growth. Conversely, the $\mathrm{NH}_{4}^{+}$content of glutamate-grown cells increased rapidly between $20 \mathrm{~h}$ and $30 \mathrm{~h}$, after which it declined steadily to a basal level. This may be attributable to a rapid breakdown of the glutamate nitrogen source within the cells as the patterns of accumulation of $\mathrm{NH}_{4}^{+}$and 2-oxoglutarate in glutamate-grown cells were similar (Fig. $3 e, f)$ and coincided with the disappearance of glutamate from the medium, which was readily accumulated by the glutamate-grown cells in the first $10 \mathrm{~h}$ of growth (see Fig. $3 \mathrm{~g}$ ). The concentration of 2-oxoglutarate in both $\mathrm{NH}_{4}^{+}$- and glutamate-grown cells increased steadily until $25 \mathrm{~h}$ growth when it was twofold higher in the glutamate-grown cells. The 2-oxoglutarate content of the $\mathrm{NH}_{4}^{+}$-grown cells then rapidly declined, so by $30 \mathrm{~h}$ that of the glutamate-grown cells was ninefold higher. The 2-oxoglutarate content of glutamate-grown cells remained twofold greater than that of $\mathrm{NH}_{4}^{+}$-grown cells throughout the rest of growth. Glutamate clearly underwent rapid catabolism in glutamate-grown cells, as only $10 \%$ of that originally accumulated remained by $30 \mathrm{~h}$. The $\mathrm{NH}_{4}^{+}$-grown cells appeared to increase their glutamate pool during the early stages of growth but after $20 \mathrm{~h}$ this also declined to a third that of the glutamate culture (Fig. $3 g$ ).

The only other metabolite to show any significant variation throughout growth was glucose 6phosphate (Fig. $3 h$ ). Between $20 \mathrm{~h}$ and $30 \mathrm{~h}$ growth, the cells from both cultures contained only trace amounts of this metabolite (which is what one could expect of a glycolytic intermediate during growth); however, the concentration of glucose 6-phosphate in $\mathrm{NH}_{4}^{+}$-grown cells rapidly increased between 30 and $60 \mathrm{~h}$, whilst in glutamate-grown cells the concentration did not rise until $50 \mathrm{~h}$ growth. It must be stressed, however, that the concentrations of metabolites observed under these conditions have been determined in a dynamic system and so reflect flux patterns of intermediates during metabolism, where an increased flux and decreased metabolism would lead to a build-up of the metabolite in question.

\section{L-Glutamate metabolism in Rs. toruloides CBS 14}

It was considered possible that the high lipid accumulation in glutamate-grown $R s$. toruloides CBS 14 was being directly caused by the nitrogen source itself, i.e. glutamate, or by one, or more, of the intermediates of its catabolism. If all the carbon from the added glutamate in a given culture was metabolized to lipid, it could only account for approximately $1 \mathrm{~g}$ of lipid (i.e. less than $20 \%$ of the total lipid). Addition of [U- ${ }^{14} \mathrm{C}$ ]glutamate to cultures of Rs. toruloides CBS 14 showed that glutamate carbon was indeed metabolized to lipid (Table 4). $\left[1,2{ }^{14} \mathrm{C}\right]$ Acetate was used as a control for the efficiency of metabolism and incorporation of a radiolabelled substrate into lipid. Of the glutamate carbon taken into the cell, $27 \%$ was recovered in the lipid fraction, indicating that not only was glutamate acting as a source of $\mathrm{NH}_{4}^{+}$(see Fig. $3 e$ ) but that the resultant 2-oxoglutarate was being actively metabolized by the cells. However, with only partial incorporation of the carbon atoms of glutamate into lipid, it was apparent that the increase in lipid concentration must be due to increased metabolic activity arising indirectly from glutamate being used as nitrogen source, rather than glutamate acting as a direct precursor of the lipid.

$\mathrm{NAD}^{+}$:glutamate dehydrogenase $\left(\mathrm{NAD}^{+}: \mathrm{GDH}\right)$ was probably responsible for the reciprocal changes in glutamate concentration with those of $\mathrm{NH}_{4}^{+}$and 2-oxoglutarate. Its specific activity was tenfold higher in glutamate-grown cells than in $\mathrm{NH}_{4}^{+}$-grown cells (Fig. $4 a$ ) in the early growth phase of the culture, i.e. between $20 \mathrm{~h}$ and $30 \mathrm{~h}$. After this time, the activity 
Table 4. Incorporation of $\left[U-^{14} C\right]$ glutamate and $\left[1,2-{ }^{14} C\right]$ acetate into lipid of $R$ s. toruloides CBS 14

Pulses $(5 \mu \mathrm{Ci})$ of radiolabelled glutamate and acetate were fed to batch cultures in vortex-aerated vessels after $35 \mathrm{~h}$ growth. Uptake and incorporation of radiolabel into cells and lipid was followed as described in Methods.

\begin{tabular}{|c|c|c|c|c|c|}
\hline \multirow[b]{2}{*}{ Culture } & \multirow{2}{*}{$\begin{array}{l}\text { Time after } \\
\text { addition of } \\
\text { radiolabel } \\
(\mathrm{min})\end{array}$} & \multicolumn{2}{|c|}{$\begin{array}{l}\text { Incorporation of } \\
\text { radiolabel into cells }(\%)\end{array}$} & \multicolumn{2}{|c|}{$\begin{array}{l}\text { Incorporation of } \\
\text { radiolabel into lipid }(\%)\end{array}$} \\
\hline & & $\begin{array}{c}\text { From } \\
\text { glutamate }\end{array}$ & $\begin{array}{c}\text { From } \\
\text { acetate }\end{array}$ & $\begin{array}{c}\text { From } \\
\text { glutamate }\end{array}$ & $\begin{array}{c}\text { From } \\
\text { acetate }\end{array}$ \\
\hline $\mathrm{NH}_{4} \mathrm{Cl}$-grown cells & $\begin{array}{l}10 \\
30 \\
45\end{array}$ & $\begin{array}{l}59 \cdot 7 \\
68 \cdot 9 \\
85 \cdot 5\end{array}$ & $\begin{array}{l}70 \cdot 4 \\
88 \cdot 7 \\
97 \cdot 5\end{array}$ & $\begin{array}{r}8 \cdot 2 \\
9 \cdot 9 \\
10 \cdot 9\end{array}$ & $\begin{array}{l}37 \cdot 9 \\
40 \cdot 2 \\
40 \cdot 9\end{array}$ \\
\hline L-Glutamate-grown cells & $\begin{array}{l}10 \\
30 \\
45\end{array}$ & $\begin{array}{l}71 \cdot 4 \\
80 \cdot 8 \\
84 \cdot 2\end{array}$ & $\begin{array}{l}74 \cdot 3 \\
89 \cdot 1 \\
96 \cdot 8\end{array}$ & $\begin{array}{l}12 \cdot 4 \\
21 \cdot 8 \\
27 \cdot 5\end{array}$ & $\begin{array}{l}41 \cdot 6 \\
42 \cdot 8 \\
44 \cdot 8\end{array}$ \\
\hline
\end{tabular}

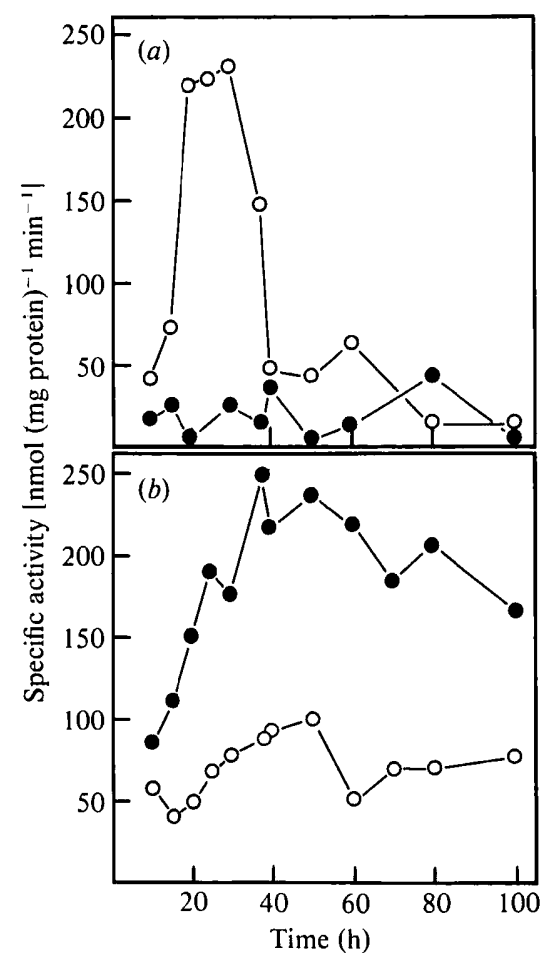

Fig. 4. Activities of the glutamate dehydrogenases of Rs. toruloides CBS 14 during batch culture with $\mathrm{NH}_{4}^{+}$and glutamate as nitrogen sources. (a) NAD ${ }^{+}$: glutamate dehydrogenase, (b) NADP ${ }^{+}$: glutamate dehydrogenase., $\mathrm{NH}_{4}^{+}$-grown cells; $\mathrm{O}$, glutamate-grown cells.

rapidly declined to a level similar to that found in $\mathrm{NH}_{4}^{+}$-grown cells. The peak in activity correlated with the depletion of the early intracellular pool of glutamate (Fig. $3 g$ ) and the concomitant production of $\mathrm{NH}_{4}^{+}$(Fig. $3 e$ ) and 2-oxoglutarate (Fig. $3 f$ ) in glutamate-grown cells. In $\mathrm{NH}_{4}^{+}$cultures, the activity of the anabolic NADP ${ }^{+}$:glutamate dehydrogenase $\left(\mathrm{NADP}^{+}: \mathrm{GDH}\right)$ increased markedly over the first $30 \mathrm{~h}$ growth and was approximately threefold higher than that in glutamate-grown cells (Fig. $4 b$ ). This activity in $\mathrm{NH}_{4}^{+}$-grown cells can therefore account for the low concentrations of intracellular $\mathrm{NH}_{4}^{+}$detected during the early stages of growth $(20-30 \mathrm{~h})$ in $\mathrm{NH}_{4}^{+}$-grown cells (Fig. $3 e$ ).

The kinetic properties of the $\mathrm{NAD}^{+}$- and $\mathrm{NADP}^{+}$-linked glutamate dehydrogenases are shown in Table 5. Although both reactions are reversible, the catabolic role of the NAD ${ }^{+}:$GDH 
Table 5. Kinetic parameters of $N A D^{+}$:glutamate and $N A D P^{+}$:glutamate dehydrogenases in Rs. toruloides CBS 14

\begin{tabular}{lcc}
\multirow{1}{*}{ Substrate } & \multicolumn{2}{c}{ Apparent $K_{\mathrm{m}}(\mathrm{mM})$} \\
\cline { 2 - 3 } $\mathrm{NAD}^{+}: \mathrm{GDH}$ & $\mathrm{NADP}^{+}: \mathrm{GDH}^{\mathrm{L}}$ \\
L-Glutamate & 3.7 & 27.9 \\
2-Oxoglutarate & 9.2 & 1.4 \\
$\mathrm{NH}_{4}^{+}$ & 26.5 & 13.0 \\
$\mathrm{NAD}^{+}$ & 0.8 & $\mathrm{ND}$ \\
\multicolumn{1}{c}{ pH optimum } & 8.2 & 8.6
\end{tabular}

ND, not determined.

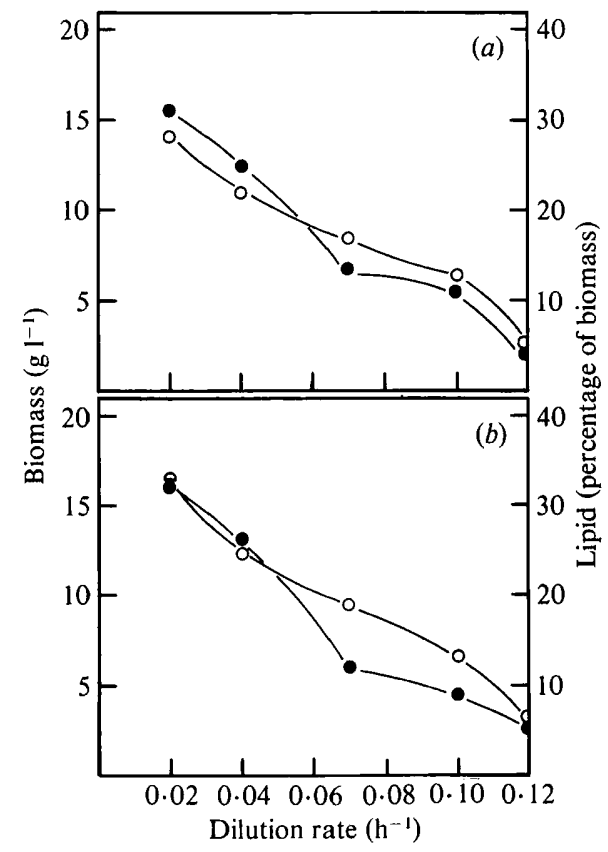

Fig. 5. Growth and lipid production by Rs. toruloides CBS 14 in continuous culture on nitrogen-limited media with $(a) \mathrm{NH}_{4} \mathrm{Cl},(b)$ L-glutamate as nitrogen sources. $\bullet$, Biomass; $\mathrm{O}$, lipid.

Table 6. Intracellular concentrations of metabolites in Rs. toruloides CBS 14 grown in continuous culture under nitrogen-limited conditions

Glucose $\left(30 \mathrm{~g}^{-1}\right)$ was used as carbon source with either $\mathrm{NH}_{4} \mathrm{Cl}\left(0.5 \mathrm{~g}^{-1}\right)$ or L-glutamate $\left(1.05 \mathrm{~g}^{-1}\right)$ as nitrogen source. $D$, dilution rate $\left(\mathrm{h}^{-1}\right)$. Concentrations are given as $\mathrm{nmol}(\mathrm{mg} \text { cell dry } \mathrm{wt})^{-1}$.

Metabolite

Citrate

Malate

Isocitrate

2-Oxoglutarate

L-Glutamate

$\mathrm{NH}_{4}^{+}$

Glucose 6-phosphate

Fructose 6-phosphate

Oxaloacetate

Extracellular citrate

$$
\text { Concn in } \mathrm{NH}_{4}^{+} \text {-grown cells }
$$

$$
\overbrace{D=0.02 \mathrm{~h}^{-1}}^{D=0.08 \mathrm{~h}^{-1}}
$$

$3 \cdot 2$

$2 \cdot 8$

1.0

4.5

4.0

1.5

0

0

0

$2 \cdot 0$
Concn in glutamate-grown cells

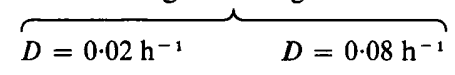


and anabolic function of the NADP ${ }^{+}$:GDH in Rs. toruloides CBS 14 are clearly expressed by their very high apparent $K_{\mathrm{m}}$ values for $\mathrm{NH}_{4}^{+}$and glutamate, respectively. These results are not dissimilar to those reported for other yeasts (Brown, 1980; Brown et al., 1974).

\section{Growth and lipid production by Rs. toruloides CBS 14 in continuous culture}

When Rs. toruloides CBS 14 was grown in a chemostat under nitrogen-limitation, the effect of L-glutamate on lipid production was lost (Fig. 5). Biomass and lipid accumulation were similar in both $\mathrm{NH}_{4}^{+}$- and glutamate-grown cultures over a range of dilution rates. The intracellular concentrations of key metabolites were monitored under steady-state conditions at two dilution rates in both cultures (see Table 6). The concentrations of most metabolites were close to the basal levels detected during batch cultures. Metabolites which accumulated to high concentrations in the glutamate-growing batch culture, i.e. $\mathrm{NH}_{4}^{+}$, L-glutamate, 2-oxoglutarate and citrate, were all found in low concentrations in the steady-state system of the chemostat.

\section{DISCUSSION}

A survey of the effect of various nitrogen sources on lipid accumulation in yeasts confirmed the early reports that certain yeasts produced much higher lipid contents when grown with an organic nitrogen source, rather than an $\mathrm{NH}_{4}^{+}$salt (Blinc \& Hočevar, 1953; Woodbine, 1959). A comparison of the growth of Rs. toruloides CBS 14, as a yeast showing this effect to the greatest degree of those examined, revealed that metabolism in glutamate-grown cells was significantly different from that in $\mathrm{NH}_{4}^{+}$-grown cells. Accumulation and excretion of citric acid was far more pronounced in the glutamate-grown cultures, which indicated that the flux of carbon to citrate in glutamate-grown cells was somehow being stimulated. The much higher concentrations of intracellular $\mathrm{NH}_{4}^{+}$and 2-oxoglutarate in glutamate-grown cells showed that catabolism of the glutamate was occurring and that these products might be indirectly responsible for the increase in cellular citrate accumulation and excretion.

In the steady-state conditions of continuous culture, the intracellular concentrations of all these metabolites in glutamate-grown cells were very low and consequently the lipid content was as low as that in $\mathrm{NH}_{4}^{+}$-grown cells. This was presumably due to the fact that under nitrogen limitation, in the steady-state system, the amount of glutamate available per cell at the slow dilution rates was very low compared to the first $30 \mathrm{~h}$ of batch culture. The study of the chemostat culture thus revealed that the increase in lipid in batch culture cells was due to a transitory phenomenon - probably the build-up of $\mathrm{NH}_{4}^{+}$(or 2-oxoglutarate) in the early stages of growth. Such a transitory state cannot, of course, arise in a chemostat under normal conditions of operation.

The difference in concentrations of $\mathrm{NH}_{4}^{+}, 2$-oxoglutarate and glutamate in cells of the batch cultures of $R$ s. toruloides CBS 14 grown on $\mathrm{NH}_{4} \mathrm{Cl}$ and on glutamate can be explained by the interplay in activity of the glutamate dehydrogenases observed during growth. Synthesis of the catabolic $\mathrm{NAD}^{+}: \mathrm{GDH}$ is derepressed (or induced) by growth on glutamate and its increased activity leads to the formation of intracellular $\mathrm{NH}_{4}^{+}$(Roon \& Even, 1973; Pateman and Kinghorn, 1976). Conversely, the activity of the anabolic NADP ${ }^{+}: \mathrm{GDH}$ increased markedly in $\mathrm{NH}_{4}^{+}$-grown cells and would consequently prevent accumulation of $\mathrm{NH}_{4}^{+}$(Brown et al., 1974; Brown 1980; Roon \& Even, 1973). The decrease in activity of the NAD ${ }^{+}: \mathrm{GDH}$ in glutamategrown cells after $30 \mathrm{~h}$ growth could be due either to its repression by $\mathrm{NH}_{4}^{+}$(Bernhardt et al., 1965; Roon \& Even, 1973) or to its rapid inactivation by reversible phosphorylation (Hemmings, 1978a, $b, 1982$ ). This would then prevent further catabolism of glutamate and build-up of $\mathrm{NH}_{4}^{+}$. The subsequent decrease in the $\mathrm{NH}_{4}^{+}$pool is then attributable to the increase in $\mathrm{NADP}^{+}:$GDH activity.

These results do not fully explain how such a large $\mathrm{NH}_{4}^{+}$pool accumulates in the first place. Possibly the various mechanisms of $\mathrm{NH}_{4}^{+}$assimilation in the cells are unaffected by growth on glutamate and hence operate only as efficiently as in $\mathrm{NH}_{4}^{+}$-grown cells. However, accumulation of glutamate from the medium and large increase in $\mathrm{NAD}^{+}: \mathrm{GDH}$ activity evidently release $\mathrm{NH}_{4}^{+}$faster than it can be assimilated, consequently increasing the pool size for a short period until the metabolism becomes adjusted. 
It is possible that catabolism of the nitrogen source in the medium, to increase pool concentrations of metabolites such as $\mathrm{NH}_{4}^{+}, 2$-oxoglutarate or glutamate, can explain how numerous other organic nitrogen sources markedly stimulate lipid production (Table 2), and these aspects are described in detail in the following paper (Evans \& Ratledge, 1984). The importance of these metabolites and the mechanisms by which they interact with the pathways of lipid biosynthesis in yeasts have been investigated, and these findings will be reported in due course.

This work was supported by a Co-operative Award in Science and Engineering from the Science and Engineering Research Council in conjunction with Cadbury-Schweppes plc.

\section{REFERENCES}

Bergmeyer, H. U. \& Bernt, E. (1974). 2-Oxoglutarate. In Methods of Enzymatic Analysis, vol. 3, pp. 1577-1582. Edited by H. U. Bergmeyer. New York: Academic Press.

Bernhardt, W., Paten, K. \& Holzer, H. (1965). Gedämpftes Oscillieren der Synthesegeschwindigkeit von DPN-abhängiger Glutamatdehydrogenase in Hefezellen. Biochimica et biophysica acta 99, 531539.

BernT, E. \& BergmeYer, H. U. (1974). L-Glutamate. In Methods of Enzymatic Analysis, vol. 4, pp. 17041715. Edited by H. U. Bergmeyer. New York: Academic Press.

Blinc, M. \& Hočevar, B. (1953). Fettanreicherung in Rhodotorula gracilis. Monatshefte für Chemie $\mathbf{8 4}$, 1127-1131.

Botham, P. A. \& Ratledge, C. (1979). A biochemical explanation for lipid accumulation in Candida 107 and other oleaginous micro-organisms. Journal of General Microbiology 114, 361-375.

Boulton, C. A. \& Ratledge, C. (1981). Correlation of lipid accumulation in yeasts with possession of ATP : citrate lyase. Journal of General Microbiology 127, 169-176.

Boulton, C. A. \& Ratledge, C. (1983). Use of transition studies in continuous cultures of Lipomyces starkeyi, an oleaginous yeast, to investigate the physiology of lipid accumulation. Journal of General Microbiology 129, 2871-2876.

BRADFORD, M. M. (1976). A rapid and sensitive method for the quantitation of microgram quantities of protein utilizing the principle of protein-dye binding. Analytical Biochemistry 72, 248-254.

Brown, C. M. (1980). Ammonia assimilation and utilization in bacteria and fungi. In Microorganisms and Nitrogen Sources pp. 511-535. Edited by J. W. Payne. London: John Wiley.

Brown, C. M., MacDonald-Brown, D. S. \& MeErs, J. L. (1974). Physiological aspects of microbial inorganic nitrogen metabolism. Advances in Microbial Physiology 11, 1-52.

BÜCHeR, T. \& PfleIderer, G. (1955). Pyruvate kinase from muscle. Methods in Enzymology 1, 435-440.

Chaney, A. L. \& Marbach, E. B. (1962). Modified reagents for determination of urea and ammonia. Clinical Chemistry 8, 130-132.

DAGLEY, S. (1974). Citrate. In Methods of Enzymatic Analysis, vol. 3, pp. 1562-1565. Edited by H. U. Bergmeyer. New York: Academic Press.

DOHERTY, D. (1970). L-Glutamate dehydrogenases (yeast). Methods in Enzymology 17A, 850-856.
Enebo, L., Anderson, L. G. \& Lundin, H. (1946). Microbiological fat synthesis by means of Rhodotorula yeast. Archives of Biochemistry 11, 383395.

Evans, C. T. \& RATledge, C. (1983a). A comparison of the oleaginous yeast, Candida curvata, grown on different carbon sources in continuous and batch culture. Lipids 18, 623-629.

Evans, C. T. \& Ratledge, C. (1983b). Biochemical activities during lipid accumulation in Candida curvata. Lipids 18, 630-635.

Evans, C. T. \& Ratledge, C. (1984). Influence of nitrogen metabolism on lipid accumulation by Rhodosporidium toruloides CBS 14. Journal of General Microbiology 130, 1705-1710.

Evans, C. T., Scragg, A. H. \& Ratledge, C. (1983). A comparative study of citrate efflux from mitochondria of oleaginous and non-oleaginous yeasts. European Journal of Biochemistry 130, 195-204.

Folch, J., Lees, M. \& Sloane-Stanley, G. H. (1957). A simple method for the isolation and purification of total lipids from animal tissues. Journal of Biological Chemistry 226, 497-509.

GutmanN, I. \& Wahlefeld, A. W. (1974). L(-)malate. In Methods of Enzymatic Analysis, vol. 3, pp. 1585-1589. Edited by H. U. Bergmeyer. New York: Academic Press.

Hemmings, B. A. (1978a). Phosphorylation of NADdependent glutamate dehydrogenase from yeast. Journal of Biological Chemistry 253, 5255-5258.

Hemmings, B. A. (1978b). Evidence for the degradation of nicotinamide adenine dinucleotide phosphate-dependent glutamate dehydrogenase of Candida utilis during rapid enzyme inactivation. Journal of Bacteriology 133, 867-877.

Hemmings, B. A. (1982). The mechanism, role and control of the inactivation of glutamate dehydrogenases in yeast. Biochemical Society Transactions 10 , 328-329.

KesSell, R. H. J. (1968). Fatty acids of Rhodotorula gracilis: Fat production in submerged culture and the particular effect of $\mathrm{pH}$ value. Journal of Applied Bacteriology 31, 220-231.

LANG, G. \& MiCHAL, G. (1974). D-Glucose 6-phosphate and D-fructose 6-phosphate. In Methods of Enzymatic Analysis, vol. 3, pp. 1238-1242. Edited by H. U. Bergmeyer. New York: Academic Press.

PATEMAN, J. A. \& KinghoRN, J. R. (1976). Nitrogen metabolism. In The Filamentous Fungi, vol. 2, Biosynthesis and Metabolism, pp. 159-237. Edited by J. E. Smith \& D. R. Berry. London: Edward Arnold. 
RATledGe, C. (1978). Lipids and fatty acids. In Economic Microbiology, vol. 2, Primary Products of Metabolism, pp. 263-302. Edited by A. H. Rose. London: Academic Press.

RAtledge, C. (1982). Microbial fats and oils: an assessment of their commercial potential. Progress in Industrial Microbiology 16, 119-206.

RatTray, J. B. M., Schibeci, A. \& Kidby, D. K. (1975). Lipids of yeasts. Bacteriological Reviews 39, 197-231.

Roon, R. J. \& Even, H. L. (1973). Regulation of the nicotinamide adenine dinucleotide- and nicotinamide adenine dinucleotide phosphate-dependent glutamate dehydrogenases of Saccharomyces cerevisiae. Journal of Bacteriology 116, 367-372.

Rutter, W. J., Hunsley, J. R., Groves, W. E., Calder, J., Rajkumar T. V. \& Woodfin, B. M.
(1966). Fructose diphosphate aldolase. Methods in Enzymology 9, 480-486.

SIEBERT, G. (1974). Isocitrate. In Methods of Enzymatic Analysis, vol. 3, pp. 1570-1573. Edited by H. U. Bergmeyer. New York: Academic Press.

Sols, A. \& Salas, M. L. (1966). Phosphofructokinase. Methods in Enzymology 9, 436-442.

Witter, B., Debuch, H. \& Steiner, M. (1974). Die Lipide von Endomycopsis vernalis bei verschiedener Stickstoff-Ernährung. Archives of Microbiology 101, 321-335.

W AHLEFELD, A. W. (1974). Oxaloacetate. In Methods of Enzymatic Analysis, vol. 3, pp. 1604-1611. Edited by H. U. Bergmeyer. New York: Academic Press. WoOdBINE, M. (1959). Microbial fat: microorganisms as potential fat producers. Progress in Industrial Microbiology 1, 181-245. 